\title{
POEMAS
}

\section{Leif IIolmstrand}

\section{Traducción de Petronella Zetterlund}

VI

entonces por qué te ofenderías solo porque otros duendes desdeñan y desprecian las maravillas sólidas de tu personalidad \# estilo \#accesorios

Claro que tiene que ver con nosotros: nosotros somos los que desdeñamos, pero solo por tu ceguera ante la necesidad de protección, tu necesidad. Tú te secas, te vuelves polvo. Nosotros echamos spray de odio contra los momentos, spray fijador sobre los garabatos diarios al carbón, un polvo permanente de plata, la animación de dibujos, nuestros momentos intrínsecos de matanza o los tuyos, un montón cada segundo.

\section{VII}

saluda amable a los falsos, no tienen la culpa de su naturaleza forzada y luego haz lo posible para que estén a gusto \#cortesía \#serenidad

Haz lo posible para sofocar la malevolencia. Basta con que hagas casi lo mejor que puedas. Luego desiste de todos tus medios y recursos $y$ ponte a nuestra disposición. Hemos deseado esto. El cuidado puede ser mutuo; los daños también.

Hemos hablado algo del odio pero el odio en realidad ha cesado. ¿Recuerdas? LPyH

Leif Holmstrand (Suecia, 1972) es escritor y artista queer multidisciplinario. Su obra literaria, experimental, incluye poesía, narrativa y dramaturgia. Los poemas que aquí se presentan pertenecen al volumen Avstå från tragedierna [Renuncia a las tragedias], Trombone, 2017. 